\title{
Cane toads and bush tucker: starvation ketoacidosis in a bushwalker
}

\author{
We describe the case of a 35-year-old woman who presented to a remote Northern \\ Territory hospital with severe metabolic acidosis after a 10-day solo bush walk, during \\ which she survived on various specimens of "bush tucker" including a cane toad.
}

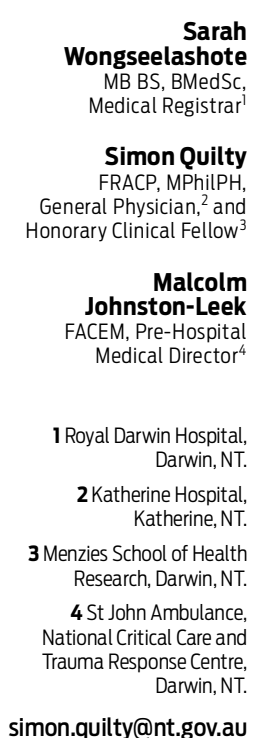

doi: $10.5694 /$ mjal3.10204

\section{Clinical record}

An otherwise fit and healthy 35-year-old woman presented to our emergency department at a remote Northern Territory hospital with vomiting and abdominal pain. An independent traveller from a southern Australian city, she had embarked 10 days earlier on a solo bushwalk into an isolated national park with the intention of living on "bush tucker" - wild plants, berries and native animals that she would find along the way. She had not sought any advice from authorities or local people before commencing her bushwalk. She followed the path of a river from which she drank fresh water throughout her journey. By Day 4 she had completely consumed her small supply of food and began eating berries that she identified using a popular Australian pictorial guide. ${ }^{1}$ On Day 6, being extremely hungry, she ate a frog that leapt into her tent, which she subsequently grilled over a spirit flame. She immediately developed nausea and vomiting and became acutely aware of the distance to medical care and her serious predicament. Still vomiting intermittently and without any food, she embarked on a 4-day march that we estimate to be around 100 kilometres to a campsite with a public telephone, where she called an ambulance.

On arrival at the hospital she was diaphoretic, nauseated and anxious. She had sunburn on exposed areas and had multiple insect bites and abrasions. Apart from a respiratory rate of 26 breaths/min, her vital signs were normal and the only abnormality on physical examination was mild epigastric tenderness. Initial venous blood gas examination showed severe metabolic acidosis with respiratory compensation (Box). Electrolytes, renal function, liver function and creatine kinase were all within normal limits, as was an electrocardiogram. She received 2L of intravenous normal saline and a sandwich, and her symptoms rapidly improved.

She was admitted and given breakfast, lunch and dinner. Eight hours later, her $\mathrm{pH}$ had normalised and the following day she was discharged.

\section{Discussion}

What had caused this patient's metabolic acidosis? The patient herself believed that toxic fumes from the spirit flame were responsible; however, this did not fit the clinical picture, and inspection of her camp stove showed that it used an ethanol-based fuel. The anion gap was raised at $37 \mathrm{mEq} / \mathrm{L}$ (reference interval, $8-16 \mathrm{mEq} / \mathrm{L}$ ), indicating the presence of unmeasured anions, as would be the case in ketoacidosis, but it was of course possible that the patient had consumed unidentified acids given her ingestion of various types of "bush tucker". Only capillary ketones were measured, which perhaps highlights the reliance of remote health services on point-of-care or "bedside" tests in the acute setting. Formal assays of ketoacids, if available, would have been informative.

Was her cane toad meal to blame? When shown an image of a cane toad (Bufo marinus), the patient was confident that this was what she had consumed, recognisable by its larger size compared with most frogs found in the region and distinctive dry and warty appearance. The cane toad has parotid glands filled with venom containing an array of toxic compounds, including large quantities of cardiac glycosides. Poisoning can result in abdominal pain and vomiting, paralysis, seizures and digitalis toxicity-like effects. $^{2,3}$ No deaths have been recorded in Australia, though it is toxic to other reptiles and is implicated in plummeting populations of the Australian death adder and other native wildlife in northern Australia. An assessment of serum digoxin levels could potentially have confirmed the toxic source, as bufatoxins from the cane toad cross-react with cardiac glycosides, however it was decided not to pursue this avenue as the duration from time of exposure to presentation was 4 days. It did seem reasonable that the toad may have caused vomiting; however, this would be expected to lead to a metabolic alkalosis. What about the red berries? A search through the patient's bush tucker book did not result in their identification, and their appearance did not match any known toxic plant found in the region. ${ }^{4}$

There are myriad dangers to be found in remote outback Australia, including a wide variety of poisonous plants and animals; ${ }^{5}$ however, none could explain this presentation. Starvation is a not uncommon cause of ketoacidosis that has been reported in a variety of settings including gastric banding, ${ }^{6}$ extreme diets and eating disorders, ${ }^{7}$ pregnancy, ${ }^{8}$ hospitalisation $^{9}$ and in combination with vomiting ${ }^{10}$ and exercise. ${ }^{11}$ The acidosis produced is generally mild, ${ }^{12}$ but there are case reports of a more severe acidosis when starvation is combined with other forms of physiological stress, such as infection and dehydration in a postpartum woman $^{13}$ and in a paediatric patient with hypoxic brain injury. ${ }^{9}$

Ketoacidosis is the result of production of ketones by the liver, a clinical picture recognised most commonly in the setting of insulin deficiency and hyperglycaemia of diabetes. In that situation, hypoinsulinaemia promotes lipolysis of peripheral fat stores and stimulates the production of ketones, which are derived from the partial oxidation of free fatty acids in the liver. ${ }^{14}$ Ketone bodies are mildly 
Venous blood gas biochemistry results at admission, showing severe metabolic acidosis with respiratory compensation

\begin{tabular}{lcc}
$\begin{array}{l}\text { Physiological } \\
\text { parameter }\end{array}$ & Result & Reference interval \\
\hline $\mathrm{pH}$ & 7.05 & $7.32-7.43$ \\
$\mathrm{PCO}_{2}$ & $12.6 \mathrm{mmHg}$ & $41-50 \mathrm{mmHg}$ \\
$\mathrm{HCO}_{3}^{-}$ & $11.6 \mathrm{mmol} / \mathrm{L}$ & $23-27 \mathrm{mmol} / \mathrm{L}$ \\
Lactate & $2.0 \mathrm{mmol} / \mathrm{L}$ & $0.5-2.2 \mathrm{mmol} / \mathrm{L}$ \\
Glucose & $6.9 \mathrm{mmol} / \mathrm{L}$ & $4.0-6.4 \mathrm{mmol} / \mathrm{L}$ \\
Base excess & $-18.5 \mathrm{mmol} / \mathrm{L}$ & -2 to $2 \mathrm{mmol} / \mathrm{L}$ \\
Capillary ketones & $7.1 \mathrm{mmol} / \mathrm{L}$ & $<0.6 \mathrm{mmol} / \mathrm{L}$
\end{tabular}

acidic, and acidosis develops when production is greater than consumption.

Although ketogenesis is pathological in the setting of diabetes, the physiological mechanism of ketone production has evolved to protect vital organs by providing them with an alternative energy source in the fasting state. When glycogen stores diminish through fasting or vigorous exercise, and an alternative energy substrate is needed for the brain and peripheral tissues, the decreasing serum glucose and insulin levels trigger release of glucagon, adrenaline, cortisol and growth hormone, which initiate breakdown of peripheral fat stores, thus sparing muscle proteins from catabolism in the earlier stages of starvation. Once lipid stores are depleted in the later stages of starvation, metabolic demands are met by catabolism of muscle and other proteins. ${ }^{10}$

Ketone bodies are produced even in the early phase of starvation (12-24 hours), but at this stage they only provide about $2 \%-3 \%$ of total body energy requirements. After 3 or more days of fasting, however, glycogen stores are largely depleted and the ketone bodies acetoacetic acid and $\beta$-hydroxybutyrate account for $30 \%-40 \%$ of total body energy requirements. ${ }^{12}$ It has been hypothesised that exercise combined with starvation is synergistic in driving ketogenic metabolism, which can lead to severe metabolic derangement, such as that seen in our patient.

There are a variety of preparatory activities that anyone planning an extended bushwalk in the Australian outback should undertake. They are: consult local people with detailed knowledge of the environment and its possible dangers; observe the rules and recommendations set out by the Parks and Wildlife Commission NT or other relevant authority and apply for the appropriate permits before setting out; take into account extreme weather variables, the dangers posed by native wildlife, food and water requirements and other unforeseen events for which a satellite phone or emergency position-indicating radio beacon could be lifesaving; and finally, exercise caution in eating bush tucker as there are many highly toxic plants and animals in Australia, and the popular pictorial bush tucker guides are no alternative to the deep understanding and knowledge that allows traditional Indigenous peoples to live safely off the country.

Competing interests: No relevant disclosures.

Received 15 Feb 2013, accepted 16 Oct 2013.

1 Low T. Bush tucker: Australia's wild food harvest. Sydney: Angus and Robertson, 1989.

2 Gowda RM, Coehn RA, Khan IA. Toad venom poisoning: resemblance to digoxin toxicity and therapeutic implications. Heart 2003; 89: el4.

3 Radford DJ, Gillies AD, Hinds JA, Duffy P. Naturally occurring cardiac glycosides. Med J Aust 1986; 144: 540-544.

4 Chippendale GM, Murray LR. Poisonous plants of the Northern Territory. Darwin: Department of Primary Industries and Fisheries, 1963.

5 Tyler MJ. Frog and cane toad skin secretions. In: Covacevich J, Davie P, Pearn J, editors. Toxic plants and animals: a guide for Australia. Brisbane: Queensland Museum, 1987: 329-339.

6 Lulsegged A, Saeed E, Langford E, et al. Starvation ketoacidosis in a patient with gastric banding. Clin Med 2011; 11: 473-475.

7 Causso C, Arrieta F, Hernández J, et al. Severe ketoacidosis secondary to starvation in a frutarian patient. Nutr Hosp 2010; 25: 1049-1052.

8 Burbos N, Shiner AM, Morris E. Severe metabolic acidosis as a consequence of acute starvation in pregnancy. Arch Gynecol Obstet 2009; 279: 399-400.

9 Toth HL, Greenbaum LA. Severe acidosis caused by starvation and stress. Am J Kidney Dis 2003; 42: El6-E19.

10 Owen D, Little S, Leach R, Wyncoll D. A patient with an unusual aetiology of a severe ketoacidosis. Intensive Care Med 2008; 34: 971-972.

11 Miaskiewicz S, Levey GS, Owen O. Severe metabolic ketoacidosis induced by starvation and exercise. Am J Med Sci 1989; 297: 178-180.

12 Owen OE, Caprio S, Reichard GA Jr, et al. Ketosis of starvation: a revisit and new perspectives. Clin Endocrinol Metab 1983; 12: 359-379.

13 Chernow B, Finton C, Rainey TG, O'Brian JT. "Bovine ketosis" in a nondiabetic postpartum woman. Diabetes Care 1982; 5: 47-49.

14 Koul PB. Diabetic ketoacidosis: a current appraisal of pathophysiology and management. Clin Pediatr (Phila) 2009; 48: 135-144.

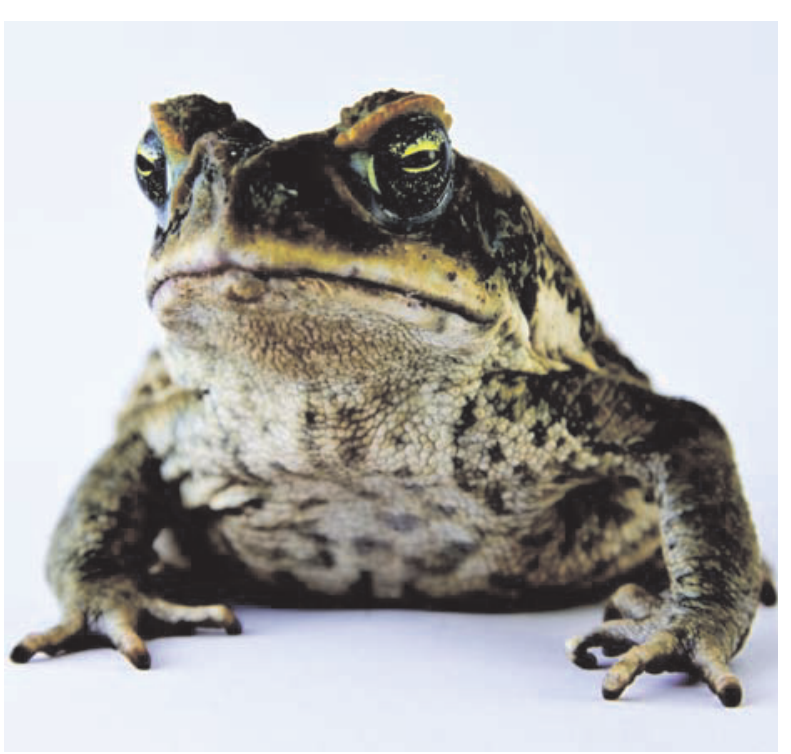

